\title{
Involvement of cAMP-Dependent Protein Kinase in the Nucleus Accumbens in Cocaine Self-Administration and Relapse of Cocaine-Seeking Behavior
}

\author{
David W. Self, ${ }^{1}$ Lisa M. Genova, ${ }^{2,3}$ Bruce T. Hope, ${ }^{2}$ William J. Barnhart, ${ }^{1}$ \\ Jennifer J. Spencer, ${ }^{1}$ and Eric J. Nestler ${ }^{1}$ \\ ${ }^{1}$ Laboratory of Molecular Psychiatry, Departments of Psychiatry and Pharmacology, Yale University School of Medicine, \\ Connecticut Mental Health Center, New Haven, Connecticut 06508, 2Molecular Plasticity Section, National Institutes of \\ Neurological Disorders and Stroke, Bethesda, Maryland 20892-4135, and 3Program in Neuroscience, Harvard University, \\ Boston, Massachusetts 02115
}

\begin{abstract}
cAMP-dependent protein kinase (PKA) in the nucleus accumbens (NAc) has been implicated in cocaine addiction because (1) cocaine reinforcement is mediated by dopamine receptors that modulate cAMP formation, and (2) repeated exposure to cocaine upregulates the cAMP system in NAc neurons. This study tested PKA involvement in cocaine self-administration and relapse of cocaine-seeking behavior by infusing CAMP analogs that activate or inhibit PKA into the NAc of rats. Bilateral intra-NAc infusions of the PKA inhibitor $R_{\mathrm{p}}$-cAMPS reduced baseline cocaine self-administration, shifted the doseresponse curve for cocaine self-administration to the left, and induced relapse of cocaine-seeking behavior after extinction from cocaine self-administration, consistent with an enhancement of cocaine effects in each paradigm. In contrast, pretreatment with intra-NAc infusions of a PKA activator, $S_{p}$-cAMPS or dibutyryl cAMP, increased baseline cocaine self-administration during the second hour of testing and shifted the dose-
\end{abstract}

response curve to the right, consistent with an antagonist-like action. After extinction from cocaine self-administration, similar infusions of Sp-cAMPS induced generalized responding at both drug-paired and inactive levers. As an index of PKA activity in vivo, NAc infusions of Rp-cAMPS reduced basal levels of dopamine-regulated phosphoprotein-32 phosphorylation and blocked amphetamine-induced increases in cAMP response element-binding protein (CREB) phosphorylation. Conversely, NAc infusions of $S_{p}$-cAMPS increased phosphorylation of CREB. Together, these results suggest that sustained upregulation of the cAMP system in the NAc after repeated cocaine exposure could underlie tolerance to cocaine reinforcement, whereas acute inhibition of this system may contribute to drug craving and relapse in addicted subjects.

Key words: Protein kinase A, reward, reinforcement, drug addiction, dopamine, drug craving, reinstatement
The mesolimbic dopaminergic projection to the nucleus accumbens (NAc) is thought to mediate the reinforcing effects of cocaine through activation of dopamine receptors on NAc neurons (Wise, 1990; Kuhar et al., 1991; Fibiger et al., 1992; Koob, 1992; Self and Nestler, 1995). Recent evidence also suggests that relapse of drug-seeking behavior can be triggered by activation of dopamine receptors in this brain region (Stewart and Vezina, 1988; Di Ciano et al., 1996; Self et al., 1996a; Shaham et al., 1996; Shaham and Stewart, 1996; Self, 1997). Dopamine signals are mediated by two major classes of dopamine receptors, termed $\mathrm{D}_{1}$ and $\mathrm{D}_{2}$-like, that are distinguishable by their structural heterogeneity (Sibley et al., 1993) and either activation or inhibition of cAMP formation, respectively (Sibley et al., 1993).

Despite their opposing actions on adenylyl cyclase activity, previous studies have found that both $\mathrm{D}_{1}$ - and $\mathrm{D}_{2}$-like classes of dopamine receptors can mediate reinforcing signals of drugs of abuse, because both $\mathrm{D}_{1}$ - and $\mathrm{D}_{2}$-like-selective dopamine agonists

Received Aug. 6, 1997; revised Dec. 1, 1997; accepted Dec. 8, 1997.

This work was supported by United States Public Heath Service Grants DA 08227, DA 00223, and DA 05603, by the Abraham Ribicoff Research Facilities of the Connecticut Mental Health Center, and by a generous gift from the William Benter Foundation. We thank Dr. Jane Taylor for comments on this manuscript.

Correspondence should be addressed to Dr. David Self, Department of Psychiatry, Yale University School of Medicine, 34 Park Street, New Haven, CT 06508.

Copyright (C) 1998 Society for Neuroscience $0270-6474 / 98 / 181848-12 \$ 05.00 / 0$ are self-administered by animals (Self and Stein, 1992a; Caine and Koob, 1993; Weed et al., 1993; Weed and Woolverton, 1995; Grech et al., 1996; Self et al., 1996b). In contrast, we recently reported that $\mathrm{D}_{1}$ - and $\mathrm{D}_{2}$-like receptor agonists produce opposite modulation of relapse in an animal model of cocaine-seeking behavior (Self et al., 1996a). Thus, although activation of $\mathrm{D}_{2}$-like receptors strongly induces cocaine-seeking behavior, activation of $\mathrm{D}_{1}$-like receptors fails to induce this behavior and blocks cocaineseeking behavior triggered by priming injections of cocaine itself. These opposing effects on cocaine-seeking behavior suggest that $\mathrm{D}_{1}$ - and $\mathrm{D}_{2}$-like receptors regulate qualitatively different motivational aspects of cocaine action, which could involve their differential modulation of cAMP-dependent protein kinase (PKA) activity in NAc neurons.

In an earlier study, we reported that inactivation of inhibitory G-proteins $\left(\mathrm{G}_{\mathrm{i}} / \mathrm{G}_{\mathrm{o}}\right)$ in the NAc produces a dopamine receptor antagonist-like effect on cocaine self-administration, suggesting that a $\mathrm{D}_{2}$-like receptor-coupled $\mathrm{G}_{\mathrm{i}} / \mathrm{G}_{\mathrm{o}}$ mechanism (possibly inhibition of cAMP formation) is an important intracellular signaling pathway used in cocaine reinforcement (Self et al., 1994). Conversely, cocaine reinforcement through stimulation of $\mathrm{D}_{1}$-like receptors in the NAc could represent a distinct dopamine receptor pathway that involves stimulatory G-proteins $\left(\mathrm{G}_{\mathrm{s}}\right)$ and increased intracellular cAMP formation (Caine et al., 1995; Self and Nestler, 1995; Self et al., 1996b), possibly in a separate 
subpopulation of NAc neurons (Gerfen et al., 1990; Le Moine et al., 1990; Meador-Woodruff et al., 1991). In either case, changes in PKA activity in NAc neurons could play a pivotal role in mediating the reinforcing signals produced by both $\mathrm{D}_{1}$ - and $\mathrm{D}_{2}$-like receptors.

In addition, PKA activity in the NAc has been generally implicated in drug addiction, because chronic exposure to several drugs of abuse upregulates cAMP formation and PKA activity specifically in this brain region (Terwilliger et al., 1991; Tjon et al., 1994; Ortiz et al., 1995; Self et al., 1995; Schoffelmeer et al., 1996; Unterwald et al., 1996). These findings raise the possibility that drug-induced upregulation of PKA activity in the NAc could contribute to motivational disturbances in drug addiction. In the present study, we directly tested the role of PKA in the NAc both in cocaine self-administration and in relapse of cocaine-seeking behavior by infusing a highly selective PKA inhibitor or activator, $R_{\mathrm{p}}$ - or $S_{\mathrm{p}}$-cAMPS, respectively, directly into the NAc. $R_{\mathrm{p}^{-}}$and $S_{\mathrm{p}}$-cAMPS are diastereoisomers of adenosine $3^{\prime}, 5^{\prime}$-(cyclic) monophosphorothioate with enhanced lipophilicity compared with CAMP (Braumann and Jastorf, 1985) and are completely resistant to degradation by phosphodiesterases (Braumann et al., 1986).

\section{MATERIALS AND METHODS}

\section{Self-administration and reinstatement}

Subjects, surgery, and apparatus. Naive, male Sprague Dawley rats initially weighing 300-325 gm (Charles River, Kingston, NY), were trained to press a lever for $45 \mathrm{mg}$ sucrose pellets under food deprivation for at least 3 consecutive days. Animals were then fed ad libitum for at least $1 \mathrm{~d}$ before surgery. Under equithesin anesthesia $(1.0 \mathrm{ml} / \mathrm{kg})$, animals were surgically implanted with a chronic indwelling jugular catheter prepared from SILASTIC tubing (0.02 in inner diameter, 0.037 in outer diameter; Green Rubber, Woburn, MA) treated with tridodecylmethyl ammonium chloride (TDMAC) heparin (Polysciences Inc., Warrington, PA), secured with Mersilene surgical mesh (General Medical, New Haven, CT) at the jugular vein. The catheter passed subcutaneously to exit the animal's back through 22 gauge tubing embedded in dental cement and secured with Marlex surgical mesh (Bard Inc., Cranston, RI). The animals were then implanted with bilateral guide cannulae (Plastics One, Roanoke, VA), in the NAc or caudate-putamen. Stereotaxic coordinates with the top of the skull level were $+1.7 \mathrm{~mm}$ anterior to bregma, \pm 1.5 $\mathrm{mm}$ lateral, and $-5.7 \mathrm{~mm}$ for NAc or $-3.7 \mathrm{~mm}$ for caudate-putamen, both ventral to dura (Paxinos and Watson, 1982). Dummy cannulae cut to extend $1.0 \mathrm{~mm}$ beyond the guide cannulae were left in place throughout the experiment. To prevent clogging, catheters were flushed daily with $0.2 \mathrm{ml}$ of heparinized $(20 \mathrm{U} / \mathrm{ml})$, bacteriostatic saline, and antibiotic ointment was applied to the catheter exit wound on the animal's back.

After a minimum $6 \mathrm{~d}$ recovery period, animals were placed in operant test chambers (Coulbourn Instruments, Lehigh, PA), and catheters were connected to a syringe pump system. Each infusion pump system consisted of a Razel (Stamford, CT) model A infusion pump and $20 \mathrm{ml}$ glass syringe connected to a fluid swivel (Stoelting, Wood Dale, IL) with Teflon tubing. Tygon tubing connected the swivel to the animal's cathetercannula assembly and was protected by a metal spring secured to a screw embedded in the catheter assembly. A single $25 \mathrm{gm}$ lever press response (FR 1) at the active lever delivered a $0.1 \mathrm{ml}$ intravenous injection of sterile-filtered cocaine (National Institute on Drug Abuse, Research Triangle Park, NC) dissolved in $0.9 \%$ saline over a $10 \mathrm{sec}$ injection interval. During infusion, a cue light above the active lever was illuminated, and the house light was extinguished. Each injection was followed by an additional $5 \mathrm{sec}$ "time-out" period in which the cue light was extinguished, and lever press responses during the total time-out period of $15 \mathrm{sec}$ (TO $15 \mathrm{sec}$ ) were recorded but had no programmed consequences. All responding at an inactive lever mounted 6 inches from the active lever were measured but had no programmed consequences.

Self-administration procedure. Animals were allowed to acquire cocaine self-administration $(0.5 \mathrm{mg} / \mathrm{kg}$ per injection $)$ in daily, $2 \mathrm{hr}$ selfadministration test sessions 5-6 d/week during their light cycle. After a minimum of 10 test sessions to acquire self-administration, animals demonstrating stable self-administration baselines (totals varied $<10 \%$ from the mean of three consecutive sessions) were assigned to various treatment groups such that the mean baseline self-administration rates in each group were similar (see Data analysis and Results). The animals were then pretreated with intracranial infusions of $R_{\mathrm{p}}$-cAMPS, $S_{\mathrm{p}}$ cAMPS (Biolog, La Jolla, CA), or the PBS vehicle, $\mathrm{pH} 7.4$, through 33 gauge bilateral injection cannulae (Plastics One) in $1.0 \mu \mathrm{l} /$ side over a 3 min period, $30 \mathrm{~min}$ before the onset of testing. In dose-response experiments, animals self-administered each dose of cocaine until baselines were stable before testing commenced with the cAMP analogs. At least $2 \mathrm{~d}$ of stable baseline responding separated each test with the cAMP analogs, and the order of dose presentation for cocaine and the cAMP analogs was counterbalanced across animals. Animals received a maximum of $8-10$ injections; the effects of the cAMP analogs were not diminished with repeated injections.

Food reinforcement procedure. In food reinforcement experiments, NAc-implanted, drug-naive animals were trained in $2 \mathrm{hr}$ test sessions to press a lever for $45 \mathrm{mg}$ sucrose pellets while maintained at $85 \%$ original body weight. Food reinforcement was delivered under an FR 1/TO 2 min schedule, where each food pellet delivery was followed by a $2 \mathrm{~min}$ time-out period when the house and cue lights were off and responding was not reinforced. As in self-administration experiments, animals were pretreated with NAc infusions of $R_{\mathrm{p}}$-cAMPS, $S_{\mathrm{p}}$-cAMPS, or vehicle 30 min before the onset of testing and at least two sessions of stable responding at the food-paired lever (reinforcement and time-out responding each varied $<10 \%$ from the mean of two consecutive sessions).

Reinstatement procedure. A within-session, daily $4 \mathrm{hr}$ reinstatement paradigm was used in which animals self-administered cocaine $(0.5$ $\mathrm{mg} / \mathrm{kg}$ per injection, i.v.) for $2 \mathrm{hr}$, followed by saline substitution for cocaine during the final $2 \mathrm{hr}$. Low baseline responding during extinction was demonstrated after three consecutive tests with less than five responses at either the drug-paired or inactive lever during the final hour of the saline phase. After demonstration of this criteria, the animals were given intracranial infusions of $R_{\mathrm{p}}$-cAMPS, $S_{\mathrm{p}}$-cAMPS, or vehicle $30 \mathrm{~min}$ into the saline phase of the next test session, and the number of nonreinforced responses was measured during the final hour of the saline phase. The order of dose presentation was counterbalanced for each cAMP analog across animals.

In a variation of the previous experiment, the effects of pretreatment with $R_{\mathrm{p}}$-cAMPS, $S_{\mathrm{p}}$-cAMPS, or vehicle on cocaine-induced reinstatement were studied by infusing the lower $40 \mathrm{nmol} /$ side dose of each cAMP analog into the NAc $30 \mathrm{~min}$ into the saline phase of the test session, which was also 30 min before intravenous priming injections of cocaine $(0.5$ and $2.0 \mathrm{mg} / \mathrm{kg})$. The number of nonreinforced responses was again measured during the final hour of the saline phase, immediately after the cocaine injection.

Histology. At the end of self-administration experiments, animals were injected with chloral hydrate $(5 \mathrm{ml} / \mathrm{kg}$, i.p., $80 \mathrm{mg} / \mathrm{ml})$ and perfused transcardially with $0.9 \%$ saline followed by $10 \%$ formalin/saline. Brains were dissected, frozen, and sliced in $40 \mu \mathrm{m}$ sections. The sections were placed on gelatin-coated slides, stained with cresyl violet, and examined for cannula placement and abnormal gliosis and scarring.

Data analysis. The effects of $R_{\mathrm{p}}$-cAMPS, $S_{\mathrm{p}}$-cAMPS, or vehicle on cocaine self-administration were analyzed by comparing selfadministration hourly totals with two-way ANOVA (dose $\times$ treatment) with repeated measures on treatment (baseline vs cAMP analogs). A within-subject analysis was used for the experiment with dibutyryl cAMP, in which data were analyzed by both one-way ANOVA with repeated measures on dose and two-way ANOVA (dose $\times$ treatment) with repeated measures on treatment. Dose-response curves for cocaine self-administration were analyzed with three-way ANOVA (cocaine dose $\times R_{\mathrm{p}}$ - or $S_{\mathrm{p}}$-cAMPS dose $\times$ treatment) with repeated measures on treatment. Baseline comparisons between $R_{\mathrm{p}}$-cAMPS-, $S_{\mathrm{p}}$-cAMPS-, and dibutyryl cAMP-treated groups for both NAc and caudate-putamen experiments were analyzed for each hour with a two-way ANOVA (baseline $\times$ group) at the $0.5 \mathrm{mg} / \mathrm{kg}$ per injection dose of cocaine. Individual treatment comparisons with baseline were made $a$ priori with Student's paired $t$ test or post hoc with Dunnett's test for comparison with vehicle. An $\alpha$ level of $\leq 0.05$ was considered statistically significant. During this analysis, one $R_{\mathrm{p}}$-cAMPS-treated animal that displayed elevated baseline self-administration was excluded to normalize mean baseline self-administration rates between $R_{\mathrm{p}}$ - and $S_{\mathrm{p}}$-cAMPS-treated animals. Also, a few tests at the highest dose of the cAMP analogs were repeated when the treatment disrupted cocaine self-administration leading to long periods without responding (a criteria of less than five 
self-injections in the first or second hour of the test session was used to retest).

In the food reinforcement experiment, the effects of the cAMP analogs on reinforcement rates, time-out responding at the food-paired lever, and inactive lever responding were each analyzed by comparing 2 hr totals with two-way ANOVA (anolog $\times$ treatment) with repeated measures on both factors. Individual treatment comparisons with baseline were made $a$ priori with Student's paired $t$ test.

In reinstatement experiments, nonreinforced responding during the final hour of the saline phase after intracranial infusions with the cAMP analogs was analyzed with one-way ANOVA with repeated measures on treatment. Post hoc comparisons with vehicle were made with Dunnett's test. Because a high degree of heterogeneity between group variances was noted in reinstatement experiments, nonparametric analyses also were conducted on individual group means with a Wilcoxon signed ranks test of related subjects. In experiments in which the cAMP analogs were infused in the NAc as a pretreatment to intravenous priming injections of cocaine, data were compared with two-way ANOVA (cocaine dose $x$ treatment) and with baseline data (always less than five responses at either lever) by the Wilcoxon signed ranks test of related subjects.

\section{PKA phosphorylation of cAMP response element-binding protein and dopamine-regulated phosphoprotein 32}

$N A c$ infusion and dissection. Under equithesin anesthesia $(1.0 \mathrm{ml} / \mathrm{kg}), 100$ gm rats were given a single unilateral infusion of $R_{\mathrm{p}}$-cAMPS or $S_{\mathrm{p}}$ cAMPS ( $80 \mathrm{nmol} / 1.0 \mu \mathrm{l}$ per side) through 33 gauge injection needles as described above, except that the contralateral side (counterbalanced across left and right) received $1.0 \mu \mathrm{l}$ of vehicle. One hundred-gram rats were used to facilitate rapid dissection and freezing to preserve phosphorylation changes; the stereotaxic coordinates for NAc inf usions were adjusted to $+1.5 \mathrm{~mm}$ anterior to bregma, $\pm 1.5 \mathrm{~mm}$ lateral, and $-6.5 \mathrm{~mm}$ ventral to dura, which corresponded to the same infusion site as in larger rats as verified by dye infusion. Rats remained anesthetized and were killed by rapid decapitation at either 1 or $2 \mathrm{hr}$ after NAc infusion. Some $R_{\mathrm{p}}$-cAMPS-treated animals were challenged with $d$-amphetamine sulfate ( $4.0 \mathrm{mg} / \mathrm{kg}$, i.p.) $15 \mathrm{~min}$ before killing. Whole brains were rapidly removed and dropped into isopentane chilled to $-40^{\circ} \mathrm{C}$ within $35 \mathrm{sec}$ of decapitation (dissection times ranged from 26 to $35 \mathrm{sec}$ ). Frozen brains were stored at -80 C. Subsequently, a 14 gauge blunted needle was used to take punches of NAc from 1-mm-thick frozen coronal slices in a cryostat chilled to $-20 \mathrm{C}$.

Immunoblotting. One hundred microliters of $2 \%$ SDS were added to microf uge tubes containing the frozen punches for immediate sonication, and total protein concentration was assayed using the bicinchinoninic acid method (Pierce, Rockford, IL). One hundred micrograms of protein/sample were loaded on a $10 \%$ acrylamide $/ 0.27 \%$ bisacrylamide SDS-polyacrylamide gel for electrophoresis and subsequently transferred electrophoretically onto an Immobilon membrane (Millipore, Bedford, MA). Blots were incubated overnight at $4^{\circ} \mathrm{C}$ with anti-Ser ${ }^{133}$ phosphocAMP response element-binding protein (CREB) antiserum at 1:1000 (Ginty et al., 1993) or anti-Thr ${ }^{34}$ phospho-dopamine-regulated phosphoprotein 32 (DARPP-32) (Snyder et al., 1992) in blocking buffer consisting of $3 \%$ nonfat dried milk powder in PBST (10 mM sodium phosphate, $\mathrm{pH}$ $7.4,0.9 \%$ sodium chloride, and $0.1 \%$ Tween 20 ). The blots were then washed with blocking buffer and incubated for $1 \mathrm{hr}$ at $20^{\circ} \mathrm{C}$ with horseradish peroxidase-conjugated donkey anti-rabbit antiserum (Amersham, Arlington Heights, IL) at a 1:2000 dilution in blocking buffer. The blots were washed in PBST, and immunoreactivity was visualized using enhanced chemiluminescence (Amersham). The resulting autoradiograms were scanned and subsequently quantitated using Imagequant (Computational Molecular Dynamics, Wayzata, MN). Under the immunoblotting conditions used, levels of immunoreactivity for phospho-CREB were linear over at least a threefold range of tissue concentrations.

Data analysis. Data from desensitized phospho-CREB immunoblots from $R_{\mathrm{p}}$ - and $S_{\mathrm{p}}$-cAMPS-treated animals at 1 and $2 \mathrm{hr}$ time points were analyzed with two-way ANOVA (time $\times$ side) using the left and right NAc as a within-subjects variable. This analysis revealed a significant main effect of side for $S_{\mathrm{p}}$-cAMPS $\left(F_{(1,4)}=2.984 ; p=0.011\right)$ but no change for $R_{\mathrm{p}}$-cAMPS $\left(F_{(1,6)}=2.267 ; p=0.183\right)$ on phospho-CREB immunoreactivity. To test whether $R_{\mathrm{p}}$-cAMPS could block amphetamine-induced increases in phospho-CREB immunoreactivity, the PBS- and $R_{\mathrm{p}}$-cAMPS-inf used sides of NAc from animals challenged with systemic amphetamine were each compared with the same control (PBS) side from $R_{\mathrm{p}}$-cAMPS-treated animals not receiving amphetamine with two-way ANOVA (time $\times$ treatment). This analysis revealed a significant main effect of treatment $\left(F_{(2,18)}=22.533 ; p<0.001\right)$ on phospho-CREB immunoreactivity. Because the treatment $\times$ time interaction was not significantly different for $S_{\mathrm{p}}$-cAMPS $\left(F_{(1,4)}=2.303 ; p=\right.$ $0.204), R_{\mathrm{p}}$-cAMPS $\left(F_{(1,6)}=1.6666 ; p=0.244\right)$, or $R_{\mathrm{p}}$-cAMPS plus amphetamine $\left(F_{(2,18)}=0.445 ; p=0.647\right)$, data from the 1 and $2 \mathrm{hr}$ time points were pooled for both phospho-CREB and phospho-DARPP-32 and subsequently analyzed with one-way ANOVA on treatment (see Fig. 5). Comparisons between vehicle and treated sides of the NAc were made a priori with Student's paired $t$ test for $R_{\mathrm{p}}$ - and $S_{\mathrm{p}}$-cAMPS and post hoc with Fisher's least significant difference (LSD) test for control, vehicle plus amphetamine, and $R_{\mathrm{p}}$-cAMPS plus amphetamine.

\section{RESULTS}

\section{Opposite and time-dependent effects of $\boldsymbol{R}_{\mathrm{p}}$ - and $S_{\mathrm{p}}$ - cAMPS infusions in the NAc on maintenance of intravenous cocaine self-administration}

Maintenance of cocaine self-administration under fixed ratio schedules is characterized by highly regular patterns of drug self-administration, in which self-administration rates can increase or decrease in response to blockade or enhancement of cocaine action, respectively (Koob and Goeders, 1989; Self and Stein, 1992b). Bilateral infusions of the PKA inhibitor $R_{\mathrm{p}}$ cAMPS and the PKA activator $S_{\mathrm{p}}$-cAMPS produced opposite effects on cocaine self-administration when infused $30 \mathrm{~min}$ before the onset of testing (Figs. 1, 2). $R_{\mathrm{p}}$-cAMPS decreased lever press responding for intravenous cocaine injections by prolonging the time interval between successive self-injections, whereas similar NAc infusions of the PKA activator $S_{\mathrm{p}}$-cAMPS increased cocaine self-administration by shortening the time interval between successive self-injections (Figs. 1,2$). R_{\mathrm{p}}$-cAMPS decreased cocaine self-administration during both the first $\left(F_{(1,26)}=14.356\right.$; $p=0.001)$ and second $\left(F_{(1,26)}=6.081 ; p=0.021\right)$ hours of the test session when compared with baseline self-administration, with a greater effect during the first hour of testing (Fig. 2, top panel). The effect of $R_{\mathrm{p}}$-cAMPS was dose-dependent during the first hour of testing (baseline $\times$ treatment interaction, $F_{(2,26)}=$ 4.547; $p=0.020)$.

In contrast, $S_{\mathrm{p}}$-cAMPS increased cocaine self-administration only during the second hour $\left(F_{(1,35)}=12.380 ; p=0.001\right)$ and was ineffective during the first hour of the test session $\left(F_{(1,35)}=0.014\right.$; $p=0.907)$. A similar increase in cocaine self-administration was produced by intra-NAc infusions of dibutyryl cAMP, another cAMP analog with PKA-activating effects (Fig. 3). In this experiment, conducted entirely within the same animals, dibutyryl cAMP also increased cocaine self-administration during the second hour of the test session when compared with either baseline self-administration $\left(F_{(1,6)}=7.054 ; p=0.038\right)$ or control inf usions with the PBS vehicle $\left(F_{(2,12)}=4.217 ; p=0.041\right)$. Like $S_{\mathrm{p}}$-cAMPS, dibutyryl cAMP was ineffective during the first hour of testing (vs baseline, $F_{(1,6)}=1.244 ; p=0.307$; vs vehicle, $F_{(2,12)}=0.562 ; p=$ $0.545)$.

Because intracerebral infusions can diffuse dorsally along the cannula shafts, control experiments were conducted in the caudate-putamen, $2 \mathrm{~mm}$ dorsal to the NAc infusion site (Fig. 2, bottom panel). The caudate-putamen is the dorsal extension of the basal ganglia and is generally not implicated in drug reinforcement mechanisms. Direct infusion of either $R_{\mathrm{p}}$ - or $S_{\mathrm{p}^{-}}$ cAMPS in the caudate-putamen produced only small changes in cocaine self-administration that were not significant during either the first $\left(F_{(1,17)}=0.135 ; p=0.780\right)$ or second $\left(F_{(1,17)}=0.018 ; p=\right.$ 0.894 ) hour of the test session compared with baseline selfadministration. In all experiments, control infusions of the PBS vehicle failed to alter cocaine self-administration, and baseline cocaine self-administration rates were similar across all experi- 


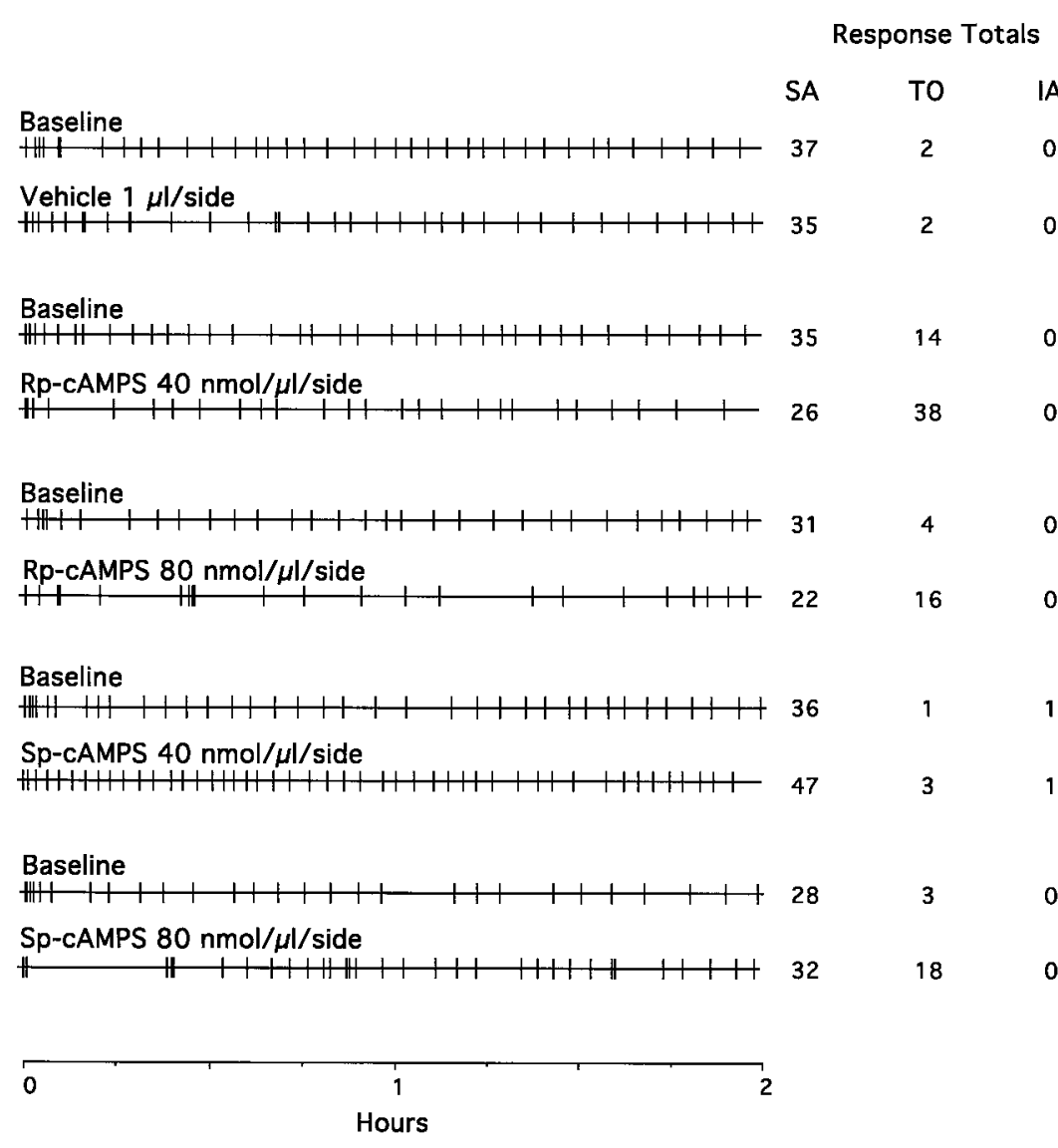

IA 0 0 0 0 0 0 1

Figure 1. Event records from representative rats selfadministering cocaine $(0.5 \mathrm{mg} / \mathrm{kg}$ per injection, i.v.) during baseline (previous test session) and $30 \mathrm{~min}$ after bilateral NAc infusions of the PKA inhibitor $R_{\mathrm{p}}$-cAMPS, the PKA activator $S_{\mathrm{p}}$-cAMPS, and the PBS vehicle during daily, $2 \mathrm{hr}$ test sessions. The vertical deflections mark the time of each self-injection response. The total number of self-injections $(S A)$, number of lever press responses during the $15 \mathrm{sec}$ time-out periods after each injection $(T O)$, and responses at the inactive lever $(I A)$ are listed to the right. NAc infusions of $R_{\mathrm{p}}$-cAMPS decreased whereas $S_{\mathrm{p}}$-cAMPS increased cocaine self-administration. Control infusions of vehicle had no effect. ments at the $0.5 \mathrm{mg} / \mathrm{kg}$ per injection dose (first hour: group means ranged from 17.8 to 22.6 self-injections $/$ hr; $F_{(13,105)}=1.468 ; p=$ 0.142 ; second hour: group means ranged from 13.6 to 18.2 selfinjections $/$ hr; $\left.F_{(13,105)}=1.722 ; p=0.067\right)$.

Animals treated with the lowest test dose of the cAMP analogs generally self-administered cocaine with highly regular response patterns. A few (11 of 69 trials) animals treated with $S_{\mathrm{p}}$-cAMPS showed stereotypical responding at the inactive lever, although the pattern of cocaine self-administration in the same animals remained regular. We have observed a similar phenomenon in a small percentage of untreated rats during cocaine selfadministration. Similarly, both $R_{\mathrm{p}}$ - and $S_{\mathrm{p}}$-cAMPS infusions increased time-out responding in some but not all animals during cocaine self-administration (e.g., Fig. 1). Although animals pretreated with $R_{\mathrm{p}}$-cAMPS displayed no obvious behavioral deficits, some $S_{\mathrm{p}}$-cAMPS-treated animals displayed increased grooming behavior. Furthermore, some animals treated with the highest dose of $S_{\mathrm{p}}$-cAMPS ( $80 \mathrm{nmol} / 1.0 \mu \mathrm{l}$ per side) displayed pronounced forepaw treading that progressed to partial motor seizure activity; hence these animals were not tested. This latter effect was never observed in animals treated with $S_{\mathrm{p}}$-cAMPS at the lower dose of $40 \mathrm{nmol} / \mu \mathrm{l}$ per side.

\section{NAc infusions of $R_{\mathrm{p}}$ - and $S_{\mathrm{p}}$-cAMPS produce opposite changes in phospho-CREB and phospho-DARPP-32 immunoreactivity}

In an effort to provide biochemical confirmation of $R_{\mathrm{p}}$ - and $S_{\mathrm{p}}$-cAMPS effects on PKA activity in the NAc in vivo, we measured the phosphorylation state of two well characterized PKA substrates, CREB and DARPP-32, by use of phosphospecific antibodies (Figs. 4, 5). Although the basal level of CREB phos- phorylation in the NAc was low and could not be reduced further by $R_{\mathrm{p}}$-cAMPS $\left(T_{7}=1.439 ; p=0.193\right)$, similar infusions of $R_{\mathrm{p}}$-cAMPS completely inhibited the $70 \%$ increase in CREB phosphorylation induced by a systemic amphetamine challenge $\left(F_{(2,21)}=25.030 ; p<0.001\right)$. In contrast, NAc infusions of $S_{\mathrm{p}}$-cAMPS increased basal CREB phosphorylation by $\sim 150 \%$ $\left(T_{5}=-3.989 ; p=0.010\right)$.

Although NAc infusions of $R_{\mathrm{p}}$-cAMPS had no effect on low basal levels of CREB phosphorylation, $R_{\mathrm{p}}$-cAMPS reduced basal DARPP-32 phosphorylation by $\sim 55 \%$ in the same tissue samples $\left(T_{4}=5.571 ; p=0.005\right)$. Conversely, unlike the increase in basal CREB phosphorylation produced by amphetamine and by $S_{\mathrm{p}}$ cAMPS, neither amphetamine $\left(T_{9}=-1.439 ; p=0.184\right)$ nor $S_{\mathrm{p}}$-cAMPS $\left(T_{2}=0.762 ; p=0.525\right)$ increased DARPP-32 phosphorylation in the same tissue samples. These findings confirm that $R_{\mathrm{p}}$-cAMPS effectively inhibits PKA activity in the NAc, whereas $S_{\mathrm{p}}$-cAMPS effectively increases PKA activity at the doses used in behavioral experiments. Interestingly, these results also suggest that CREB and DARPP-32 apparently exist in differential basal states of phosphorylation in the NAc in vivo, with low basal levels of phosphorylated CREB and high basal levels of phosphorylated DARPP-32.

\section{NAc infusions of $R_{\mathrm{p}}$ - and $S_{\mathrm{p}}$-cAMPS produce opposite shifts in the dose-response curve for cocaine self-administration}

Cocaine self-administration is highly dose-dependent such that increasing the unit dose of cocaine per injection decreases the number of self-injections taken, presumably because the animal compensates to maintain roughly equivalent cocaine levels in the brain (Koob and Goeders, 1989; Self and Stein, 1992b). Figure 6, 


\section{Nucleus Accumbens}

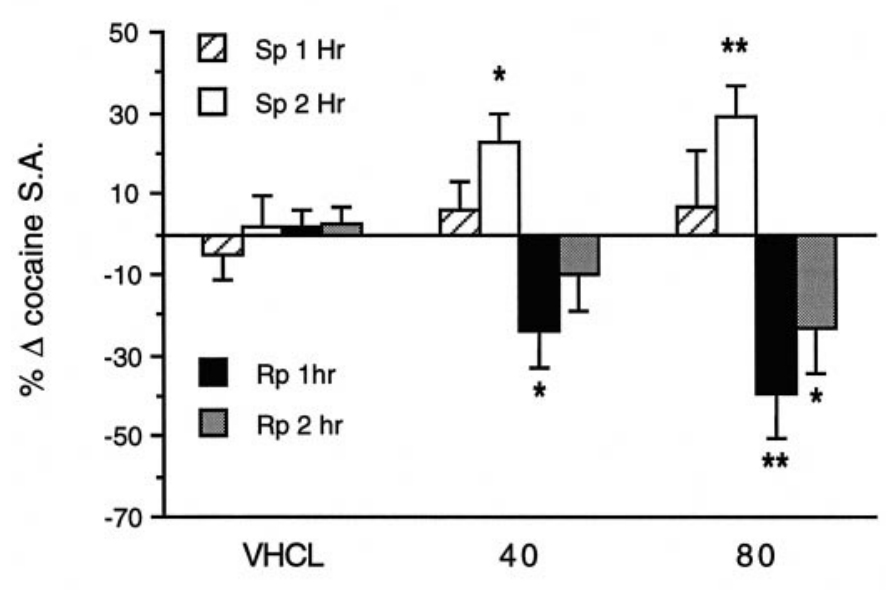

Caudate Putamen

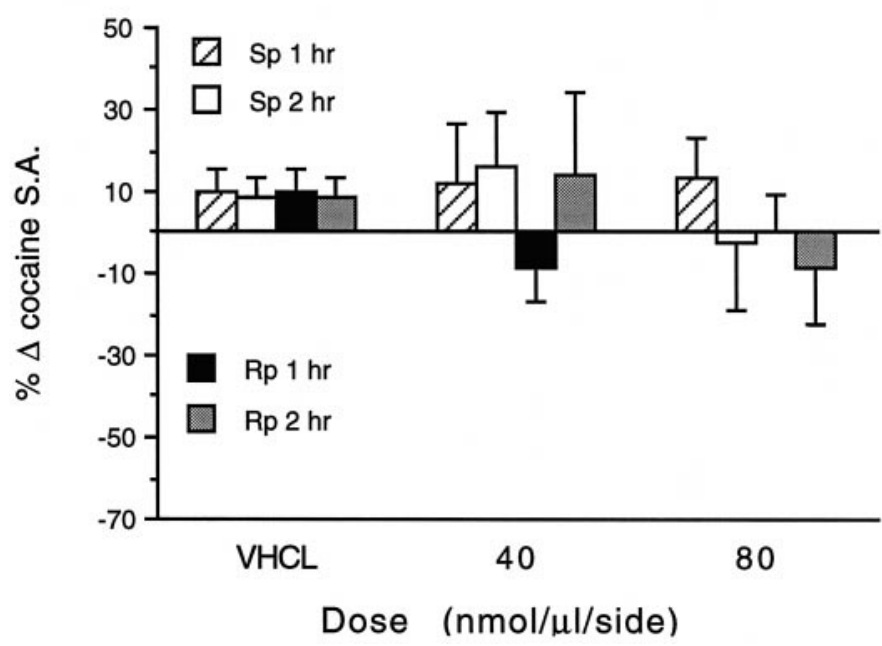

Figure 2. Effects of bilateral infusions of $R_{\mathrm{p}}$-cAMPS, $S_{\mathrm{p}}$-cAMPS, or vehicle $(V H C L)$ in the NAc (top panel, $n=8-14$ ) or in the caudateputamen $2 \mathrm{~mm}$ dorsal to the NAc site (bottom panel, $n=5-7$ ) on cocaine self-administration $(0.5 \mathrm{mg} / \mathrm{kg}$ per injection, i.v. $)$. Hourly selfadministration rates (S.A.) are expressed as the mean \pm SEM of each animal's percent change from baseline self-administration rates from the previous test session. Asterisks indicate that values differ from baseline values by paired $t$ test $\left({ }^{*} p<0.05 ;{ }^{*} p<0.01\right)$.

$A$ and $B$, shows the effects of pretreatment with bilateral NAc infusions of $R_{\mathrm{p}}$ - and $S_{\mathrm{p}}$-cAMPS on the dose-response curves for cocaine self-administration. Dose-response data were analyzed for the hour of maximal effectiveness of $R_{\mathrm{p}}$ - and $S_{\mathrm{p}}$ cAMPS on cocaine self-administration. NAc infusions of the PKA inhibitor $R_{\mathrm{p}}$-cAMPS reduced intravenous cocaine selfadministration from baseline rates at each dose of cocaine $\left(F_{(1,56)}=61.875 ; p<0.001\right)$ without disrupting the inverse relationship between injection dose and the number of selfinjections taken by the animals (treatment $\times$ cocaine dose $\times$ $R_{\mathrm{p}}$-cAMPS dose interaction, $\left.F_{(2,56)}=0.218 ; P<0.805\right)$. Thus, $R_{\mathrm{p}}$-cAMPS produced leftward shifts in the dose-response curve for cocaine self-administration.

Conversely, NAc infusions of $S_{\mathrm{p}}$-cAMPS increased cocaine self-administration from baseline at each dose of cocaine

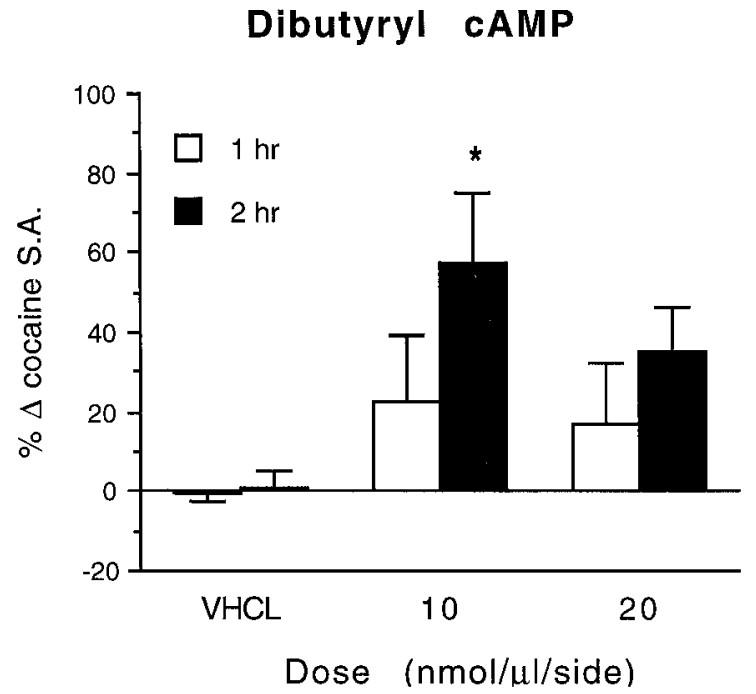

Figure 3. Effects of bilateral infusions of dibutyryl cAMP or vehicle $(V H C L)$ in the NAc on cocaine self-administration $(0.5 \mathrm{mg} / \mathrm{kg}$ per injection, i.v.). Hourly self-administration rates (S.A.) are expressed as the mean $\pm \operatorname{SEM}(n=7)$ of each animal's percent change from baseline self-administration rates from the previous test session. The asterisk indicates that values differ from both baseline values (paired $t$ test) and from rates after control infusions of vehicle (Dunnett's test) in the same animals $\left({ }^{*} p<0.05\right)$.

$\left(F_{(1,65)}=39.231 ; p<0.001\right)$, without disrupting the inverse relationship between injection dose and the number of selfinjections taken by the animals (treatment $\times$ cocaine dose $\times$ $S_{\mathrm{p}}$-cAMPS dose interaction, $\left.F_{(2,65)}=0.498 ; p<0.610\right)$. Thus, $S_{\mathrm{p}}$-cAMPS produced rightward shifts in the dose-response curve for cocaine self-administration. In contrast to $R_{\mathrm{p}}$ cAMPS, the highest dose of $S_{\mathrm{p}}$-cAMPS failed to produce a further shift in cocaine self-administration, although a further increase at the highest unit dose per injection of cocaine was observed.

\section{Lack of effect of NAc infusions of $R_{p}$ - and $S_{p}$-cAMPS on food-reinforced behavior}

There was no effect of bilateral NAc infusions of $R_{\mathrm{p}^{-}}$or $S_{\mathrm{p}^{-}}$ cAMPS (40 nmol $/ \mu 1$ per side) on lever press responding for food pellets under a FR 1/TO 2 min schedule $\left(F_{(2,14)}=1.552 ; p<\right.$ $0.246)$, in which rates of food reinforcement were similar to rates of cocaine reinforcement in the self-administration experiments (Fig. 7A). Under these conditions, each food-reinforced response was followed by a $2 \mathrm{~min}$ "time-out" period, during which responding was not reinforced. Animals generally responded with high rates at the food-paired lever near the end of each time-out period, presumably in anticipation of food availability. Figure $7 B$ shows that NAc infusions of $R_{\mathrm{p}}$-cAMPS significantly decreased high response rates during the time-out periods at the active lever $\left(F_{(2,14)}=5.086 ; p=0.022\right)$ and low response rates at the inactive lever (Fig. $\left.7 C ; F_{(2,14)}=5.988 ; p=0.022\right) . S_{\mathrm{p}}$-cAMPS had no effect on high levels of time-out responding at the food-paired lever or on lower response rates at the inactive lever (Fig. 7B,C).

\section{Relapse of cocaine-seeking behavior after NAc infusions of the PKA inhibitor $\boldsymbol{R}_{\mathrm{p}}$-cAMPS}

We next studied the influence of cAMP analogs in the NAc on relapse in an animal model of cocaine-seeking behavior (Self et al., 1996a). In this paradigm, saline is substituted for cocaine after $2 \mathrm{hr}$ of cocaine self-administration. After extinction from cocaine 

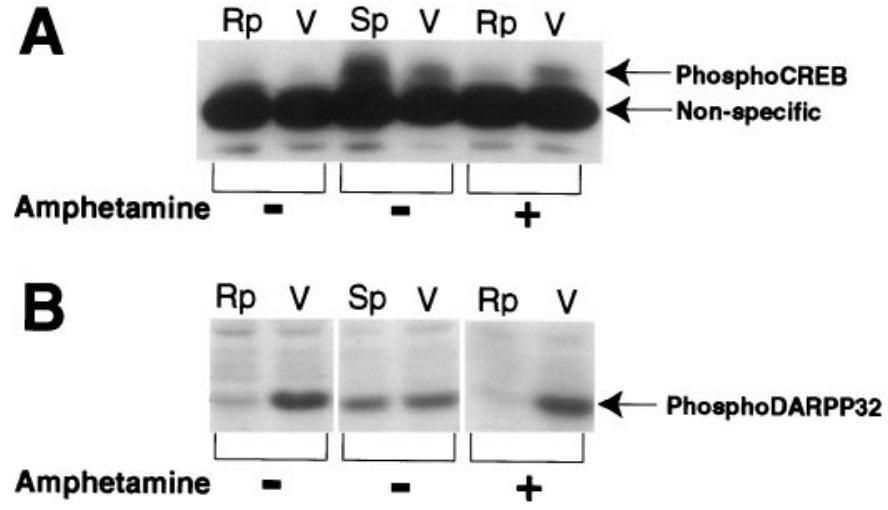

Figure 4. Autoradiograms showing the effects of NAc infusion of the PKA inhibitor $R_{\mathrm{p}}$-cAMPS $(R p)$, the PKA activator $S_{\mathrm{p}}$-cAMPS $(S p)$, or vehicle $(V)$ on phospho-CREB and phospho-DARPP-32 immunoreactivity in NAc homogenates. The cAMP analogs were both infused at a dose of $80 \mathrm{nmol}$ in $1.0 \mu \mathrm{l}$, whereas the contralateral side received similar inf usions of vehicle $1 \mathrm{hr}$ before killing. Some $R_{\mathrm{p}}$-treated animals received a challenge injection of amphetamine $(4.0 \mathrm{mg} / \mathrm{kg}$, i.p.) $15 \mathrm{~min}$ before killing. $R_{\mathrm{p}}$-cAMPS inhibited basal levels of phospho-DARPP-32 ( first lane) and prevented amphetamine-stimulated phospho-CREB ( fifth lane) immunoreactivity. In contrast, a NAc infusion of $S_{\mathrm{p}}$-cAMPS increased basal phospho-CREB immunoreactivity but had no effect on basal phospho-DARPP-32 immunoreactivity (third lane).

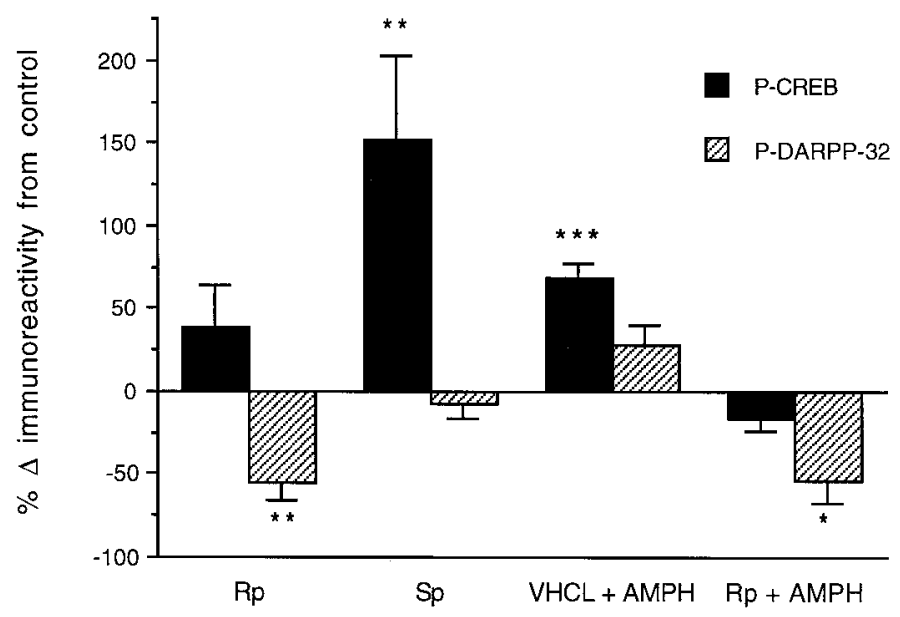

Figure 5. Effects of NAc infusions of $R_{\mathrm{p}}$-cAMPS $(R p)$ and $S_{\mathrm{p}}$-cAMPS $(S p)$ at a dose of $80 \mathrm{nmol}$ in $1.0 \mu l$ and systemic amphetamine ( $A M P H, 4.0$ $\mathrm{mg} / \mathrm{kg}$, i.p.) on phospho-CREB $(n=6-8)$ and phospho-DARPP-32 $(n=$ 3-6) immunoreactivity in NAc homogenates. Separate groups of animals were given unilateral infusions of the cAMP analogs concurrent with vehicle infusions into the contralateral side and killed 1-2 $\mathrm{hr}$ later (see Results). Some animals were challenged with amphetamine $15 \mathrm{~min}$ before killing. Data are expressed as percent change in immunoreactivity from the contralateral side for $R p$ and $S p\left({ }^{* *} p<0.01\right.$, Student's paired $t$-test). Values for amphetamine in vehicle-treated $(V H C L)$ and $R_{\mathrm{p}}$-treated sides are expressed as a percentage of the vehicle-inf used side of $R_{\mathrm{p}}$-treated animals not receiving amphetamine $\left({ }^{*} p<0.05 ;{ }^{* *} p<0.001\right.$, Fisher's LSD test).

self-administration, animals were given bilateral NAc inf usions of the cAMP analogs. The PKA inhibitor $R_{\mathrm{p}}$-cAMPS effectively induced cocaine-seeking behavior, as indicated by reinstatement of nonreinforced responding selectively at the drug-paired lever (Figs. 8, 9, top left panel). The onset of responding generally occurred 15-30 min after an $R_{\mathrm{p}}$-cAMPS infusion. $R_{\mathrm{p}}$-cAMPS induced dose-dependent increases in responding at the drugpaired lever when compared with control infusions of vehicle

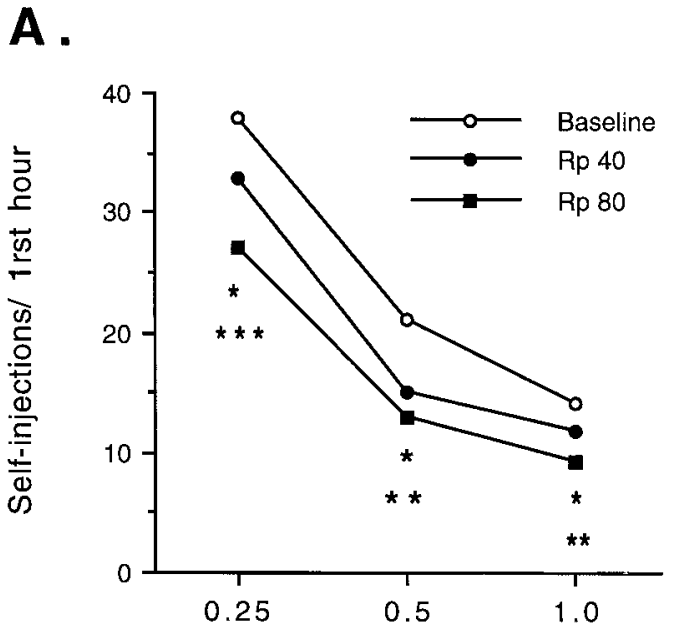

B.

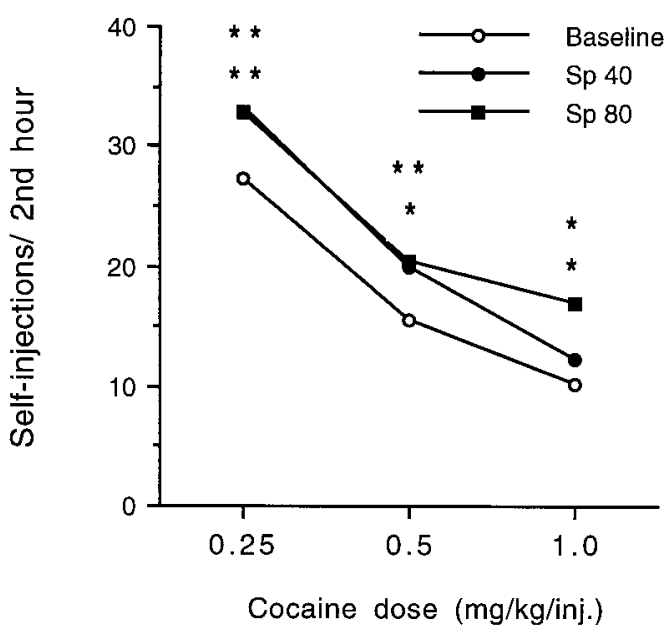

Figure 6. Effects of bilateral NAc infusions of $R_{\mathrm{p}}$-cAMPS $(A)$ or $S_{\mathrm{p}}$-cAMPS $(B)$ on the dose-response relationship of cocaine selfadministration. Self-administration rates are shown for the first hour of the test session in experiments with $R_{\mathrm{p}}$-cAMPS and during the second hour in experiments with $S_{\mathrm{p}}$-cAMPS, when the cAMP analogs produced their maximal behavioral effects (see Fig. 2). The data are expressed as the mean number of self-injections $(n=10-12)$. Baseline values represent pooled data from tests preceding both the 40 and $80 \mathrm{nmol} / 1.0 \mu \mathrm{l}$ per side doses of each cAMP analog. Asterisks indicate that values differ from baseline values by paired $t$ test for the 40 or $80 \mathrm{nmol} /$ side dose $\left({ }^{*} p<0.05\right.$; $* * p<0.01 ; * * p=0.001)$

$\left(F_{(2,18)}=5.497 ; p=0.014\right)$, whereas responding at the inactive lever remained low $\left(F_{(2,18)}=1.588 ; p=0.232\right)$. Similar infusions of $R_{\mathrm{p}}$-cAMPS in the caudate-putamen, $2 \mathrm{~mm}$ dorsal to the NAc infusion site, induced lower but selective responding (Fig. 9, top right panel) that approached significance at the drug-paired lever $\left(F_{(2,14)}=3.510 ; p=0.058\right)$ and not at the inactive lever $\left(F_{(2,14)}=\right.$ $0.990 ; p=0.396)$. Nonparametric analysis revealed a significant effect of $R_{\mathrm{p}}$-cAMPS infused in the caudate-putamen on responding at the drug-paired lever compared with control infusions of vehicle.

In contrast to $R_{\mathrm{p}}$-cAMPS, NAc priming infusions of the PKA activator $S_{\mathrm{p}}$-cAMPS induced responding at both the drug-paired and inactive levers (Fig. 9, bottom left panel). Although the effect of $S_{\mathrm{p}}$-cAMPS was not significant by ANOVA at the drug-paired $\left(F_{(2,22)}=2.755 ; P=0.086\right)$ or the inactive $\left(F_{(2,22)}=1.294 ; p=\right.$ 

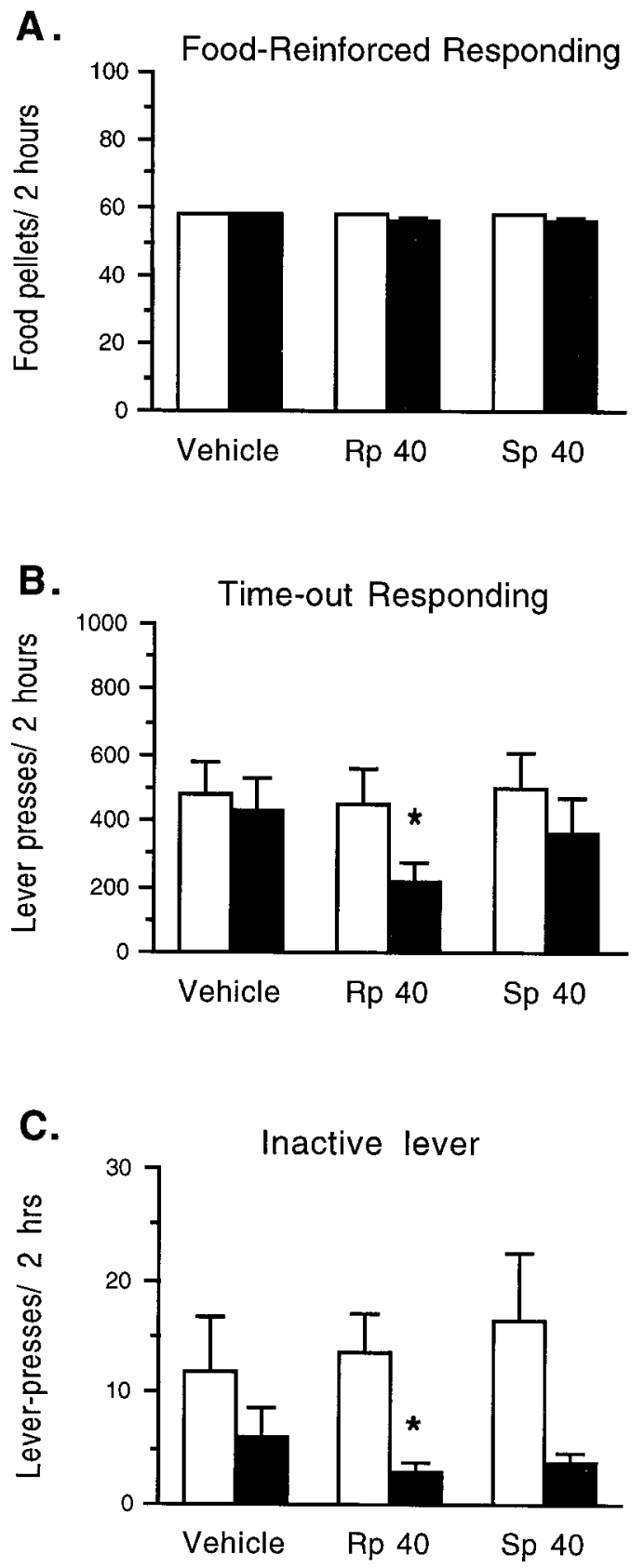

Figure 7. Effects of bilateral NAc inf usions of $R_{\mathrm{p}}$-cAMPS or $S_{\mathrm{p}}$-cAMPS (40 nmol $/ \mu \mathrm{l}$ per side) or vehicle on food-reinforced responding. Each food-reinforced response was followed by a 2 min time-out period when subsequent responding was not reinforced. Under these conditions, food reinforcement rates approached a maximum of 60 food pellets in $2 \mathrm{hr}$. Open bars show baseline responding; solid bars show the effect of NAc infusions. Data are expressed as the mean $\pm \operatorname{SEM}(n=8)$ for the rate of food reinforcement $(A)$, for nonreinforced lever press responding during the time-out periods $(B)$, and for responding at the inactive lever $(C)$. Asterisks indicate that values differ from baseline values by paired $t$ test $\left({ }^{*} p<0.05\right)$.

0.294) lever, nonparametric analysis revealed a significant effect of NAc $S_{\mathrm{p}}$-cAMPS infusions at either lever when compared with vehicle-infused controls. Priming infusions of $S_{\mathrm{p}}$-cAMPS in the caudate-putamen (Fig. 9, bottom right panel) induced minor but significant responding at the drug-paired lever $\left(F_{(2,14)}=3.828\right.$; $p=0.047)$ but not at the inactive lever $\left(F_{(2,14)}=0.304 ; p=\right.$ $0.742)$.

Enhancement of cocaine-induced relapse of cocaineseeking behavior by NAc infusions of the PKA inhibitor $\boldsymbol{R}_{\mathrm{p}}$-cAMPS

Figures 10 and 11 show the effect of pretreatment with a threshold dose of the PKA inhibitor $R_{\mathrm{p}}$-cAMPS on reinstatement of lever press responding induced by priming injections of cocaine. Pretreatment with $R_{\mathrm{p}}$-cAMPS in the NAc enhanced the priming induced by cocaine at the drug-paired lever $\left(F_{(1,50)}=4.303 ; p=\right.$ $0.043)$ but not at the inactive lever $\left(F_{(1,50)}=0.178 ; p=0.675\right)$, when compared with the vehicle-pretreated condition. Nonparametric analysis found that $R_{\mathrm{p}}$-cAMPS potentiated reinstatement of responding induced by a subthreshold dose of $0.5 \mathrm{mg} / \mathrm{kg}$ cocaine (Fig. 11, left panel).

In contrast to $R_{\mathrm{p}}$-cAMPS, pretreatment with $S_{\mathrm{p}}$-cAMPS failed to alter cocaine-induced reinstatement of responding at the drugpaired $\left(F_{(1,50)}=0.012 ; p=0.913\right)$ or inactive $\left(F_{(1,50)}=0.255 ; p=\right.$ $0.616)$ lever when compared with the vehicle-pretreated condition (Fig. 11). Although nonparametric analysis found that animals pretreated with $S_{\mathrm{p}}$-cAMPS and injected with either priming dose of cocaine responded significantly more at both levers when compared with the baseline condition (Fig. 11), this responding did not differ from responding induced by the same dose of $S_{\mathrm{p}}$-cAMPS when given alone in the previous experiment (drugpaired lever, $F_{(2,37)}=0.465 ; p=0.631$; inactive lever, $F_{(2,37)}=$ 1.053; $p=0.359)$. However, there was a tendency for better discrimination of the drug-paired lever in $S_{\mathrm{p}}$-cAMPS-treated animals after a priming injection of cocaine.

\section{Cannula placements and histology}

Figure 12 shows the location of infusion sites from animals in the NAc and caudate-putamen experiments. All NAc inf usions sites were within the boundaries of the NAc, mainly in the core region. Infusion sites in the caudate putamen generally were found in the ventromedial region. Cresyl violet-stained sections showed no evidence of abnormal gliosis or scarring after infusion of the cAMP analogs.

\section{DISCUSSION}

Role of NAc PKA activity in cocaine self-administration NAc infusions of the PKA activators and inhibitor produced opposite shifts in the dose-response curve for cocaine selfadministration. The PKA activators, $S_{\mathrm{p}}$-cAMPS and dibutyryl cAMP, increased the rate of intravenous cocaine selfadministration by reducing the time interval between successive self-injections. The effect of the PKA activators resembles the effect of reducing the unit dose of cocaine per injection (Koob and Goeders, 1989; Self and Stein, 1992b) or of pretreating animals with systemic (De Wit and Wise, 1977; Roberts and Vickers, 1984; Woolverton, 1986; Koob et al., 1987; Britton et al., 1991; Corrigall and Coen, 1991; Hubner and Moreton, 1991) or intra-NAc (Phillips et al., 1983; Caine et al., 1995) infusions of $\mathrm{D}_{1}$ - and $\mathrm{D}_{2}$-like dopamine receptor antagonists, suggesting that the PKA activators shorten the duration of cocaine effects in a manner consistent with dopamine receptor antagonism. Conversely, NAc infusions of the PKA inhibitor $R_{\mathrm{p}}$-cAMPS reduced the rate of cocaine self-administration by prolonging the interval between successive self-injections. The effect of the PKA inhibitor resembles the effect of increasing the unit dose of cocaine per injection or of pretreating animals with systemic $\mathrm{D}_{2}$-like (Yokel 

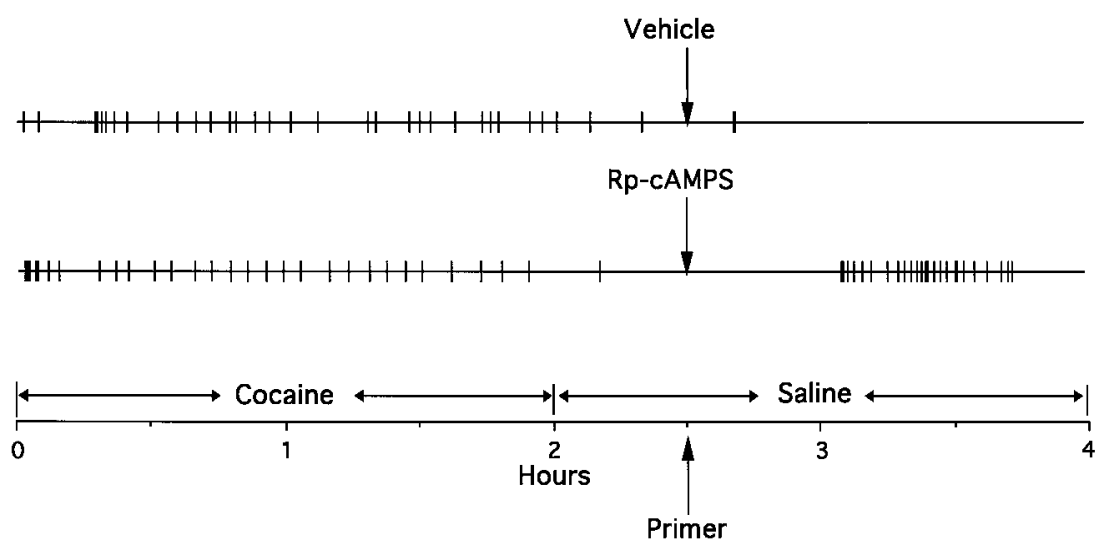

Figure 8. Event records from a representative rat showing reinstatement of nonreinforced lever press responding at the drug-paired lever after bilateral NAc-priming infusions of the PKA inhibitor $R_{\mathrm{p}}$-cAMPS $(80 \mathrm{nmol} / \mu \mathrm{l}$ per side) or vehicle during the reinstatement paradigm. NAc-priming infusions were given after extinction from $2 \mathrm{hr}$ of intravenous cocaine self-administration $(0.5$ $\mathrm{mg} / \mathrm{kg}$ per injection), when only intravenous saline injections were available. The vertical deflections mark the times of each self-injection of cocaine in the cocaine phase and of saline in the saline phase.
Nucleus Accumbens


Caudate Putamen



Figure 9. Effects of bilateral priming infusions of $R_{\mathrm{p}}$-cAMPS, $S_{\mathrm{p}}$-cAMPS, or vehicle $(V H C L)$ in the NAc $(n=10-12)$ or caudate-putamen $(n=8)$ on nonreinforced lever press responding. Data are expressed as the mean \pm SEM of total lever press responses during the final hour of the saline phase, $30 \mathrm{~min}$ after priming infusions with the cAMP analogs at doses of 40 and $80 \mathrm{nmol} / 1.0 \mu \mathrm{l} \mathrm{per}$ side, or vehicle. Responding at the drugpaired or inactive lever differs from the vehicle condition by Dunnett's test $\left({ }^{*} p<\right.$ $\left.0.05 ;{ }^{*} p<0.01\right)$ or by the Wilcoxon signed ranks test of related subjects $\left({ }^{+} p<0.05 ;{ }^{++} p<0.01\right)$. and Wise, 1978; Hubner and Koob, 1990; Caine and Koob, 1993; Pulvirenti and Koob, 1994; Caine and Koob, 1995) but not $\mathrm{D}_{1}$-like (Self et al., 1996a) dopamine receptor agonists, suggesting that the PKA inhibitor prolongs the duration of cocaine effects similar to $\mathrm{D}_{2}$-like dopamine receptor activation.

To our knowledge, opposing shifts in cocaine selfadministration dose-response curves have only been reported after opposite modulation of dopamine receptor function. Although this may suggest that modulation of PKA activity alters reinforcing signals mediated by dopamine receptors, the possibility that PKA modulation of other receptor responses contributes to this effect cannot be ruled out. For example, modulation of cocaine self-administration has been reported after blockade of NMDA glutamate receptors (Pulvirenti et al., 1992; Pierce et al., 1997), which are known to be modulated by PKA activity (Raymond et al., 1994; Colwell and Levine, 1995). However, NMDA receptor antagonists failed to shift the full dose-response curve for cocaine self-administration in these studies, and complementary effects with NMDA receptor agonists have not been reported.

The effects of $R_{\mathrm{p}^{-}}$and $S_{\mathrm{p}}$-cAMPS on cocaine selfadministration cannot be explained by generalized performance effects on lever press responding, because the cAMP analogs produced differential effects on this behavior in three different 
Figure 10. Event records from a representative rat showing the effects of pretreatment with bilateral NAc infusions of $R_{\mathrm{p}}$-cAMPS or $S_{\mathrm{p}}$-cAMPS (40 $\mathrm{nmol} / \mu \mathrm{l}$ per side) or vehicle on reinstatement of nonreinforced lever press responding induced by an intravenous priming injection of cocaine $(2.0 \mathrm{mg} / \mathrm{kg})$. Priming injections of cocaine were given $30 \mathrm{~min}$ after the NAc pretreatments during the saline phase of the reinstatement paradigm. The vertical deflections mark the times of each selfinjection of cocaine in the cocaine phase and saline in the saline phase.
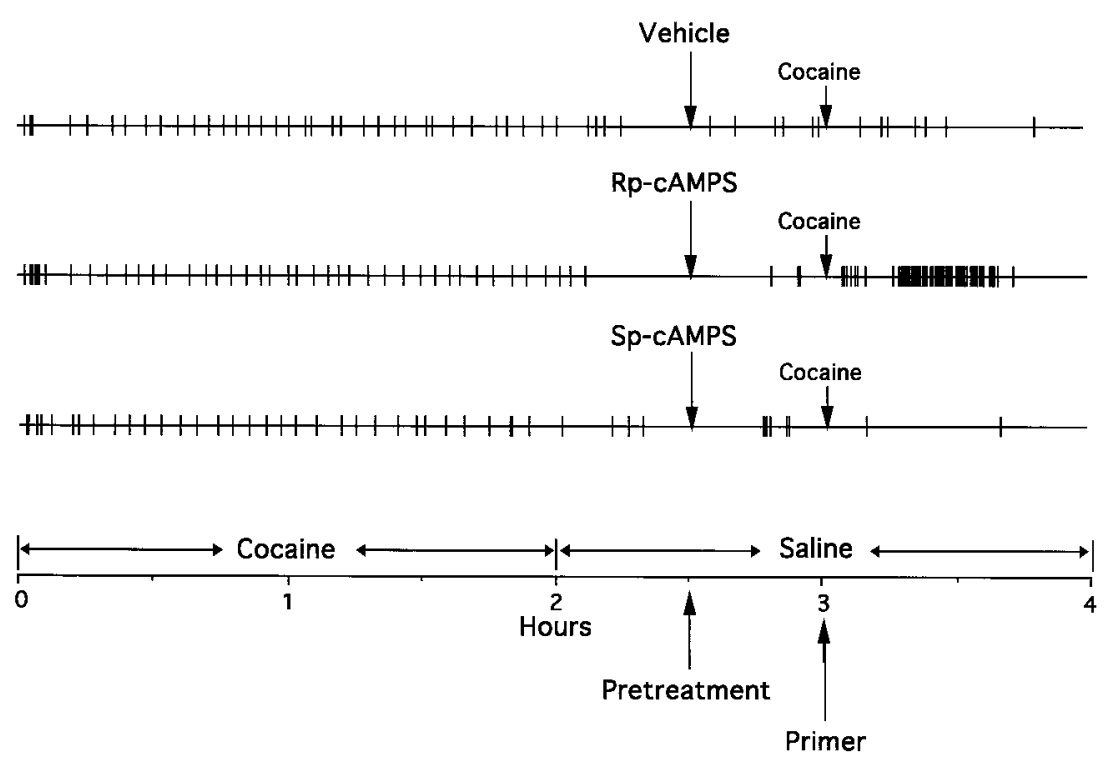

Figure 11. Effects of pretreatment with bilateral infusions of $R_{\mathrm{p}}$-cAMPS or $S_{\mathrm{p}}$-cAMPS $(40 \mathrm{nmol} / \mu \mathrm{l}$ per side) or vehicle $(V H C L)$ on nonreinforced lever press responding induced by priming injections of cocaine $(n=13-15)$. Data are expressed as the mean \pm SEM of total lever press responses during the final hour of the saline phase, $30 \mathrm{~min}$ after the NAc pretreatments with cAMP analogs, and immediately after an intravenous priming injection of cocaine $(0.5$ and $2.0 \mathrm{mg} / \mathrm{kg})$. Responding at the drug-paired or inactive lever differs from the baseline condition $(<5$ responses at either lever) by the Wilcoxon signed ranks test of related subjects $\left({ }^{+} p<0.05 ;{ }^{++} p<\right.$ $0.01)$.
A.

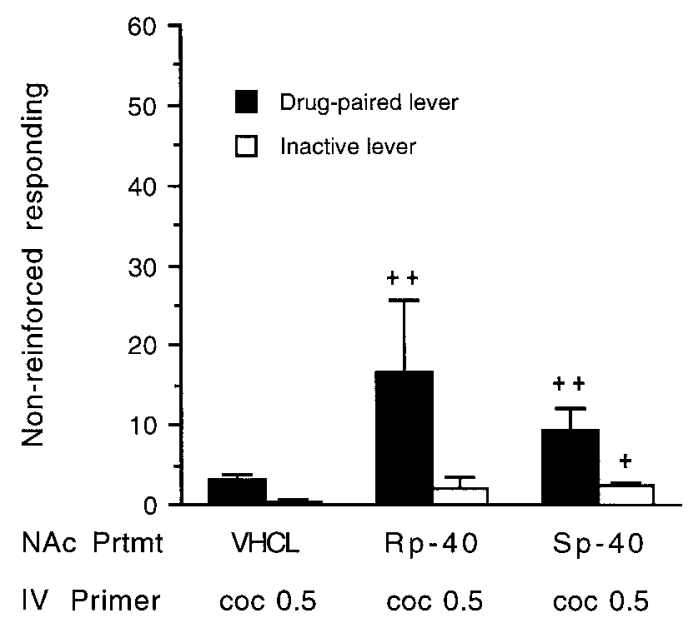

B.

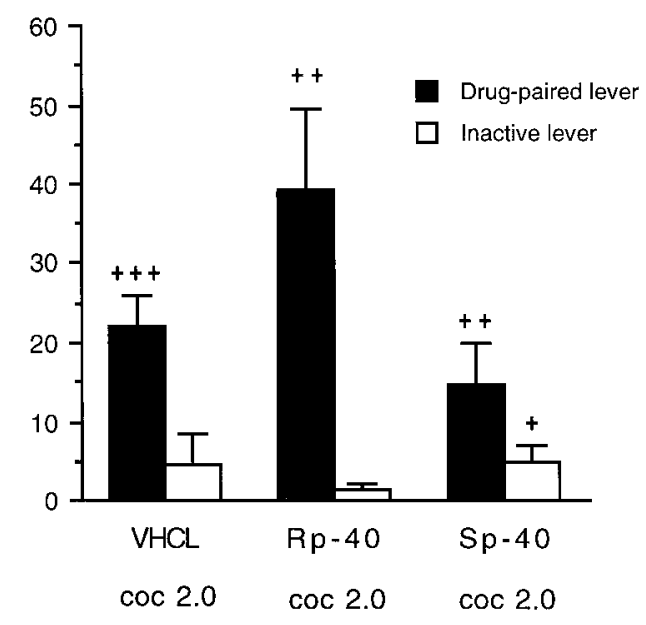

Table 1. Effect of NAc infusions of Rp-cAMPS and Sp-cAMPS on lever press responding in cocaine selfadministration (SA), food reinforcement (Rft), and reinstatement (Rstmt)

\begin{tabular}{|c|c|c|c|c|c|c|}
\hline & \multicolumn{3}{|l|}{ Rp-cAMPS } & \multicolumn{3}{|l|}{ Sp-cAMPS } \\
\hline & Cocaine SA & Food Rft & Rstmt & Cocaine SA & Food Rft & Rstmt \\
\hline Reinforcers & $\Downarrow$ & no $\Delta$ & & 个 & no $\Delta$ & \\
\hline Non-reinforced responding & no $\Delta$ or $\Uparrow$ & $\Downarrow$ & 个 & no $\Delta$ or $\Uparrow$ & no $\Delta$ & 个 \\
\hline Inactive lever & no $\Delta$ & $\Downarrow$ & no $\Delta$ & no $\Delta$ or $\Uparrow$ & $\Downarrow$ or no $\Delta$ & 个 \\
\hline
\end{tabular}

paradigms (Table 1). Thus, NAc inf usions of $R_{\mathrm{p}}$-cAMPS reduced reinforced lever press responding under an FR 1/TO $15 \mathrm{sec}$ schedule of cocaine reinforcement and nonreinforced responding during the time-out periods under an FR 1/TO 2 min schedule of food reinforcement but increased nonreinforced responding in reinstatement experiments. In contrast, NAc infusions of $S_{\mathrm{p}}$ cAMPS increased reinforced lever press responding during cocaine self-administration and nonreinforced responding in reinstatement, but had no effect on nonreinforced responding during the time-out periods in food reinforcement. Inactive lever re- sponding in reinstatement was increased, while inactive lever responding in the food reinforcement experiment tended to decrease. Although the schedule of food reinforcement generated higher levels of overall lever press behavior than cocaine selfadministration experiments, neither $R_{\mathrm{p}}$ - nor $S_{\mathrm{p}}$-cAMPS altered the rate of food reinforcement, suggesting that food reinforcement mechanisms were not affected under these conditions.

Animals treated with the cAMP analogs generally selfadministered cocaine with highly regular interinjection intervals, although the highest dose of the cAMP analogs tended to disrupt 


\section{Nucleus Accumbens}

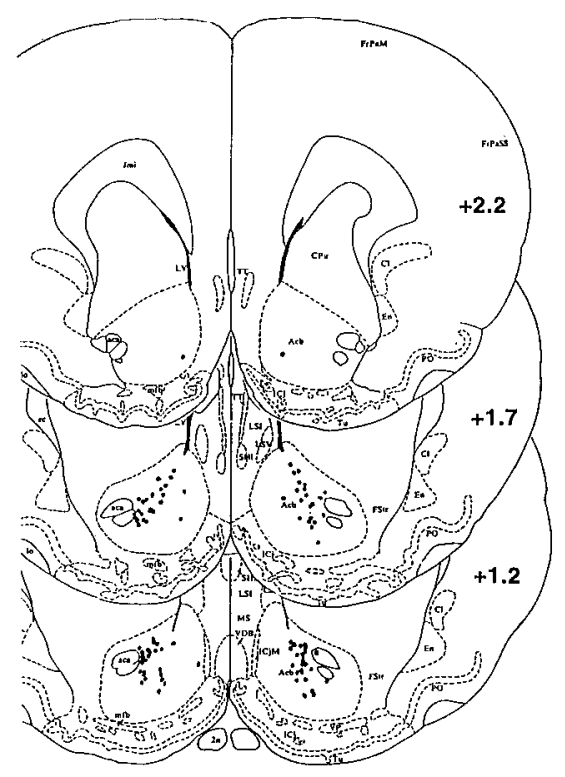

Caudate Putamen

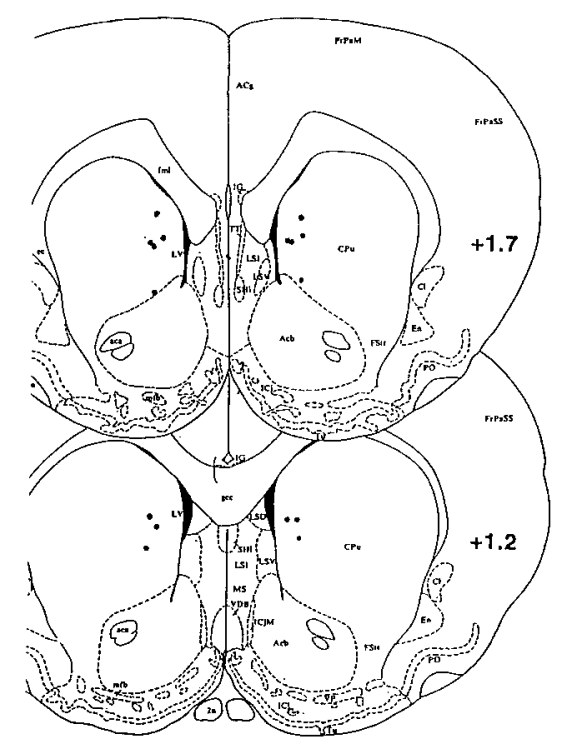

Figure 12. Localization of infusion sites in the NAc and caudate-putamen experiments. $\mathrm{CPu}$, caudate putamen, Acb, nucleus accumbens, aca, anterior commissure, (from Paxinos and Watson, 1982). self-administration patterns early in the test period. Importantly, the inverse relationship between the unit dose of cocaine selfadministered and the number of self-injections taken was preserved, indicating that animals treated with the cAMP analogs were capable of regulating their drug intake under these conditions.

To verify the effectiveness of $R_{\mathrm{p}}$ - and $S_{\mathrm{p}}$-cAMPS on PKA catalytic activity in vivo, we studied the effect of NAc infusions of cAMP analogs on the phosphorylation state of the nuclear transcription factor CREB (Yamamoto et al., 1988; Gonzalez and Montminy, 1989) and the cytosolic protein phosphatase inhibitor DARPP-32 (Hemmings and Greengard, 1986). NAc infusions of $R_{\mathrm{p}}$-cAMPS decreased basal phosphorylation of DARPP-32 and inhibited amphetamine-induced increases in the phosphorylation of CREB. In contrast, NAc infusions of $S_{\mathrm{p}}$-cAMPS or systemic amphetamine increased basal CREB phosphorylation. Although the effects of $R_{\mathrm{p}}$ - and $S_{\mathrm{p}}$-cAMPS on cocaine self-administration may not involve CREB or DARPP-32 phosphorylation per se, these phosphoproteins demonstrate the effectiveness of $R_{\mathrm{p}}-$ and $S_{\mathrm{p}}$-cAMPS on PKA activity in vivo.

$R_{\mathrm{p}}$ - and $S_{\mathrm{p}}$-cAMPS produced opposite effects on PKAmediated phosphorylation that were similar at both 1 and $2 \mathrm{hr}$ after infusion into the NAc (see Fig. 4 and Materials and Methods). Thus, whereas $R_{\mathrm{p}}$-cAMPS-induced decreases in PKA phosphorylation coincide with decreases in cocaine selfadministration at both time points, $S_{\mathrm{p}}$-cAMPS-induced increases in cocaine self-administration were evident only during the second hour of the test session. The temporal dissociation of behavioral and biochemical effects suggests that the antagonist-like action of $S_{\mathrm{p}}$-cAMPS on cocaine self-administration may be caused by a secondary neuroadaptation to sustained PKA activity. One possible explanation is that PKA activation attenuates reinforcing signals by promoting phosphorylation and desensitization of $\mathrm{D}_{1}$-like receptors, leading to a $\mathrm{D}_{1}$-like, antagonist-like effect on cocaine self-administration (Koob et al., 1987; Caine et al., 1995). Studies conducted in vitro suggest that sustained $\mathrm{D}_{1}$-like receptor stimulation can desensitize these receptors in $\sim 90 \mathrm{~min}$ (Balmfourth et al., 1990; Barton and Sibley, 1990), consistent with the development of $S_{\mathrm{p}}$-cAMPS-induced increases in cocaine selfadministration in vivo. It is also possible that $\mathrm{D}_{1}$-like receptormediated reinforcement uses an alternative signaling pathway. For example, $\mathrm{D}_{1}$-like receptor-stimulated phosphoinositide hydrolysis in striatal slices is antagonized by $S_{\mathrm{p}}$-cAMPS and enhanced by $R_{\mathrm{p}}$-cAMPS (Undie and Friedman, 1994), effects similar to modulation of cocaine self-administration.

Another possibility is that PKA activators exert presynaptic actions such as increased dopamine or glutamate release from nerve terminals (Santiago and Westerink, 1990; Chavez-Noriega and Stevens, 1994). However, increased dopamine and glutamate release in the NAc would be expected to augment rather than oppose cocaine effects, because blockade of dopamine (Caine et al., 1995) and glutamate (Pulvirenti et al., 1992) receptors in this region produces an antagonist-like effect on cocaine selfadministration. Still, another possibility is that the cAMP analogs could act on cell surface adenosine receptors to alter cocaine self-administration, but these effects would tend to be immediate, rather than delayed as we observed. Moreover, because we have observed similar increases in cocaine self-administration after NAc infusions of $S_{\mathrm{p}}$-cAMPS, dibutyryl cAMP, cholera toxin (D. W. Self and E. J. Nestler, unpublished observations), and pertussis toxin (Self et al., 1994), all of which increase cAMP activity through distinct mechanisms, it is unlikely that these effects are attributable to a cAMP-independent mechanism.

\section{Role of NAc PKA in relapse of cocaine-seeking behavior}

NAc infusions of the PKA inhibitor $R_{\mathrm{p}}$-cAMPS dosedependently induced relapse of cocaine-seeking behavior, as indicated by the induction of nonreinforced responding selectively at the drug-paired lever after extinction from cocaine selfadministration. Furthermore, NAc pretreatments with $R_{\mathrm{p}}$ cAMPS, at a dose with low priming ability when given alone, enhanced the cocaine-seeking behavior induced by low intravenous doses of cocaine. We recently reported similar effects after systemic priming injections of $\mathrm{D}_{2}$-like (but not $\mathrm{D}_{1}$-like) dopamine receptor agonists (Self et al., 1996a). Taken together, these results 
raise the possibility that relapse of cocaine-seeking behavior can be induced by inhibition of PKA activity in NAc neurons expressing $\mathrm{D}_{2}$-like receptors.

In contrast to the PKA inhibitor, NAc priming inf usions of the PKA activator $S_{\mathrm{p}}$-cAMPS induced generalized, nonreinforced responding at both the drug-paired and inactive levers. Generalized responding at both levers suggests an impairment in the animals' ability to discriminate the drug-paired from the inactive lever accurately. The mechanism for this effect is unknown but could involve possible presynaptic rather than postsynaptic effects of $S_{\mathrm{p}}$-cAMPS that disrupt information processing through dopamine and glutamate nerve terminals (Santiago and Westerink, 1990; Chavez-Noriega and Stevens, 1994). In contrast to selfadministration experiments, both $R_{\mathrm{p}}$ - and $S_{\mathrm{p}}$-cAMPS produced small but significant effects when infused into the caudateputamen in reinstatement experiments. Although these effects could be explained by possible diffusion to the NAc border $\sim 1$ $\mathrm{mm}$ ventral to the caudate-putamen, the role of the caudateputamen in relapse of cocaine-seeking behavior is unknown and could contribute to cocaine-seeking behavior induced by concaine and other priming stimuli.

\section{Neuroadaptations in NAc PKA to chronic drug exposure: implications for tolerance and relapse in drug addiction}

Previous reports have found that chronic exposure to cocaine or other drugs of abuse upregulates the cAMP second messenger system specifically in the NAc. This upregulation is characterized by increases in adenylyl cyclase and PKA activity and decreases in the levels of inhibitory G-proteins (see the introductory remarks). Given our findings that sustained, but not acute, increases in PKA activity produce antagonist-like increases in cocaine self-administration, it is possible that tonic upregulation of the NAc-cAMP system after repeated exposure to cocaine may represent an intracellular mechanism of tolerance to the reinforcing effects of cocaine. Thus, artificially mimicking cocaine-induced neuroadaptations in the NAc by downregulating inhibitory G-proteins (Self et al., 1994) or by inducing sustained PKA activation (present study) both lead to compensatory increases in cocaine self-administration. These data, along with similar findings produced by tonic stimulation of $\mathrm{G}_{\mathrm{s}}$-proteins with cholera toxin (Self and Nestler, unpublished observations), seemingly are in opposition to a recent study wherein cholera toxin-induced $G_{s}$ activation in the NAc has been reported to enhance conditioned secondary reinforcement (Kelley and Holahan, 1997). Possible reasons for this discrepancy may include different mechanisms of primary and secondary reinforcement or different effects of PKA activity on reinforcement mechanisms in basal and cocainestimulated states.

The possible contribution of tonic upregulation of the NAc cAMP system in drug craving and relapse is less straightforward, because we found that acutely it is inhibition, and not activation, of PKA in the NAc that triggers relapse of cocaine-seeking behavior. One possibility is that tonic upregulation of the NAc cAMP system after chronic drug exposure could enhance the relative signal strength generated by phasic priming stimuli that inhibit PKA activity during drug withdrawal. If so, the priming ability of stimuli that release dopamine in the NAc, leading to $\mathrm{D}_{2}$-like dopamine receptor-mediated inhibition of PKA activity, would be markedly enhanced in addicted subjects. Although this hypothesis requires further investigation, the present behavioral results provide functional relevance for drug-induced neuroadap- tations in NAc PKA activity in certain motivational changes associated with cocaine addiction.

\section{REFERENCES}

Balmfourth AJ, Warburton P, Ball SG (1990) Homologous desensitization of the dopamine $\mathrm{D}_{1}$ receptor. J Neurochem 55:2111-2116.

Barton AC, Sibley DR (1990) Agonist-induced sensitization of $\mathrm{D}_{1}$ dopamine receptors linked to adenylyl cyclase activity in cultured NS20Y neuroblastoma cells. J Pharmacol Exp Ther 38:531-541.

Braumann T, Erneux C, Petridis G, Stohrer WD, Jastorff B (1986) Hydrolysis of cyclic nucleotides by a purified cGMP-stimulated phosphodiesterase: structural requirements for hydrolysis. Biochim Biophys Acta 871:199-206.

Braumann T, Jastorff B (1985) Physiochemical characterization of cyclic nucleotides by reversed phase high-performance liquid chromatography. II. Quantitative determination of hydrophobicity. J Chromatogr 350:105-118.

Britton DR, Mackenzie RG, Kebabian JW, Williams JEG, Kerkmen D (1991) Evidence for involvement of both D1 and D2 receptors in maintaining cocaine self-administration. Pharmacol Biochem Behav 39:911-915.

Caine SB, Heinrichs SC, Coffin VL, Koob GF (1995) Effects of the dopamine D-1 antagonist SCH 2390 microinjected into the accumbens, amygdala or striatum on cocaine self-administration in the rat. Brain Res 692:47-56.

Caine SB, Koob GF (1993) Modulation of cocaine self-administration in the rat through D-3 dopamine receptors. Science 260:1814-1816.

Caine SB, Koob GF (1995) Pretreatment with the dopamine agonist 7-OH-DPAT shifts the cocaine self-administration dose-effect function to the left under schedules in the rat. Behav Pharmacol 6:333-347.

Chavez-Noriega LE, Stevens CF (1994) Increased neurotransmitter release at excitatory synapses produced by direct activation of adenylate cyclase in rat hippocampal slices. J Neurosci 14:310-317.

Colwell CS, Levine MS (1995) Excitatory synaptic transmission in neostriatal neurons: regulation by cyclic AMP-dependent mechanisms. J Neurosci 15:1704-1713.

Corrigall WA, Coen KM (1991) Cocaine self-administration is increased by both D1 and D2 dopamine antagonists. Pharmacol Biochem Behav 39:799-802.

De Wit H, Wise RA (1977) Blockade of cocaine reinforcement in rats with the dopamine receptor blocker pimozide, but not with noradrenergic blockers phentolamine and phenoxybenzamine. Can J Psychol 31:195-203.

Di Ciano P, Blaha CD, Phillips AG (1996) Comparisons of CS ${ }^{ \pm}$induced changes in dopamine in the nucleus accumbens of rats following either self- or yoked-administration of $d$-amphetamine. Soc Neurosci Abstr 22:707.

Fibiger HC, Phillips AG, Brown EE (1992) The neurobiology of cocaine-induced reinforcement. Ciba Found Symp 166:96-124.

Gerfen CR, Engber TM, Mahan LC, Susel Z, Chase TN, al. e (1990) D1 and D2 dopamine receptor-regulated gene expression of striatonigral and striatopallidal neurons. Science 250:1429-1432.

Ginty DD, Kornhauser JM, Thompson MA, Bading H, Mayo KE, Takahashi JS, Greenberg ME (1993) Regulation of CREB phosphorylation in the superchiasmatic nucleus by light and a circadian clock. Science 260:238-241.

Gonzalez GA, Montminy MR (1989) Cyclic AMP stimulates somatostatin gene transcription by phosphorylation of CREB at serine 133. Cell 59:675-680.

Grech DM, Spealman RD, Bergman J (1996) Self-administration of $D_{1}$ receptor agonists by squirrel monkeys. Psychopharmacology (Berl) 125:97-104.

Hemmings HCJ, Greengard P (1986) DARPP-32, a dopamine-regulated phosphoprotein. Prog Brain Res 69:149-159.

Hubner CB, Koob GF (1990) Bromocriptine produces decreases in cocaine self-administration in the rat. Neuropsychopharmacology 3:101-108

Hubner CB, Moreton JB (1991) Effects of selective $\mathrm{D}_{1}$ and $\mathrm{D}_{2}$ dopamine antagonists on cocaine self-administration in the rat. Psychopharmacology (Berl) 105:151-156.

Kelley AE, Holahan MR (1997) Enhanced reward-related responding following cholera toxin infusion into the nucleus accumbens. Synapse $26: 46-54$.

Koob GF (1992) Drugs of abuse: anatomy, pharmacology and function of reward pathways. Trends Pharmacol Sci 13:177-184. 
Koob GF, Goeders NE (1989) Neuroanatomical substrates of drug selfadministration. In: The neuropharmacological basis of reward (Leibman JM, Cooper SJ, eds), pp 214-263. Oxford: Clarendon.

Koob GF, Le HT, Creese I (1987) The $\mathrm{D}_{1}$ dopamine receptor antagonist SCH 23390 increases cocaine self-administration in the rat. Neurosci Lett 79:315-320.

Kuhar MJ, Ritz MC, Boja JW (1991) The dopamine hypothesis of the reinforcing properties of cocaine. Trends Neurosci 14:299-302.

Le Moine C, Normand E, Guitteny AF, Fouque B, Teoule R, Bloch B (1990) Dopamine receptor gene expression by enkephalin neurons in rat forebrain. Proc Natl Acad Sci USA 87:230-234.

Meador-Woodruff JH, Mansour A, Healy DJ, Kuehn R, Zhou Q-Y, Bunzow JR, Akil H, Civelli O, Watson SJ (1991) Comparison of the distribution of D1 and D2 dopamine receptor mRNAs in rat brain. Neuropsychopharmacology 5:231-242.

Ortiz J, Fitzgerald LW, Charlton M, Lane S, Trevisan L, Guitart X, Shoemaker W, Duman RS, Nestler EJ (1995) Biochemical actions of chronic ethanol exposure in the mesolimbic dopamine system. Synapse 21:289-298.

Paxinos G, Watson GC (1982) The Rat Brain in Stereotaxic Coordinates. New York: Academic.

Phillips AG, Broekkamp CL, Fibiger HC (1983) Strategies for studying the neurochemical substrates of drug reinforcement in rodents. Prog Neuropsychopharmacol Biol Psychiatry 7:585-590.

Pierce RC, Meil WM, Kalivas PW (1997) The NMDA antagonist, dizocilpine, enhances cocaine reinforcement without influencing mesoaccumbens dopamine transmission. Psychopharmacology (Berl) 133:188-195.

Pulvirenti L, Koob GF (1994) Dopamine receptor agonists, partial agonists and psychostimulant addiction. Trends Pharmacol Sci 15:374-379.

Pulvirenti L, Maldonado-Lopez R, Koob GF (1992) NMDA receptors in the nucleus accumbens modulate intravenous cocaine but not heroin self-administration in the rat. Brain Res 594:327-330.

Raymond LA, Tingley WG, Blackstone CD, Roche KW, Huganir RL (1994) Glutamate receptor modulation by protein phosphorylation. J Physiol (Lond) 88:181-192.

Roberts DCS, Vickers G (1984) Atypical neuroleptics increase selfadministration of cocaine: an evaluation of a behavioral screen for antipsychotic activity. Psychopharmacology (Berl) 82:135-139.

Santiago M, Westerink BHC (1990) Role of adenylate cyclase in the modulation of the release of dopamine: a microdialysis study in the striatum of the rat. J Neurochem 55:169-174.

Schoffelmeer AN, Voorn P, Jonker AJ, Wardeh G, Nestby P, Vanderschuren LJ, De Vries TJ, Mulder AH, Tjon GH (1996) Morphineinduced increase in D-1 receptor regulated signal transduction in rat striatal neurons and its facilitation by glucocorticoid receptor activation: possible role in behavioral sensitization. Neurochem Res 21:1417-1423.

Self DW (1997) The neurobiology of relapse. In: Handbook on drug abuse (Karch S, ed), pp 442-463. Boca Raton, FL: CRC.

Self DW, Nestler EJ (1995) Molecular mechanisms of drug reinforcement and addiction. Annu Rev Neurosci 18:463-495.

Self DW, Stein L (1992a) The $\mathrm{D}_{1}$ agonists SKF 82958 and SKF 77434 are self-administered by rats. Brain Res 582:349-352.

Self DW, Stein L (1992b) Receptor subtypes in opioid and stimulant reward. Pharmacol Toxicol 70:87-94.

Self DW, Terwilliger RZ, Nestler EJ, Stein L (1994) Inactivation of $\mathrm{G}_{\mathrm{i}}$ and $G_{o}$ proteins in nucleus accumbens reduces both cocaine and heroin reinforcement. J Neurosci 14:6239-6247.
Self DW, McClenahan AW, Beitner-Johnson D, Terwilliger RZ, Nestler EJ (1995) Biochemical adaptations in the mesolimbic dopamine system in response to heroin self-administration. Synapse 21:312-318.

Self DW, Barnhart WJ, Lehman DA, Nestler EJ (1996a) Opposite modulation of cocaine-seeking behavior by $\mathrm{D}_{1 \text { - }}$ and $\mathrm{D}_{2}$-like dopamine receptor agonists. Science 271:1586-1589.

Self DW, Belluzzi JD, Kossuth S, Stein L (1996b) Self-administration of the $\mathrm{D}_{1}$ agonist SKF 82958 is mediated by $\mathrm{D}_{1}$, and not $\mathrm{D}_{2}$, receptors. Psychopharmacology 123:303-306.

Shaham Y, Stewart J (1996) Effects of opioid and dopamine receptor antagonists on relapse induced by stress and re-exposure to heroin in rats. Psychopharmacology 125:385-391.

Shaham Y, Rajabi H, Stewart J (1996) Relapse to heroin-seeking in rats under opioid maintenance: the effects of stress, heroin priming, and withdrawal. J Neurosci 16:1957-1963.

Sibley DR, Monsma Jr FJ, Shen Y (1993) Molecular neurobiology of dopaminergic receptors. Int Rev Neurobiol 35:391-415.

Snyder GL, Girault J-A, Chen JYC, Czernik AJ, Kebabian JW, Nathanson JA, Greengard P (1992) Phosphorylation of DARPP-32 and protein phosphatase inhibitor-1 in rat choroid plexus: regulation by factors other than dopamine. J Neurosci 12:3071-3083.

Stewart J, Vezina P (1988) A comparison of the effects of intraaccumbens injections of amphetamine and morphine on reinstatement of heroin intravenous self-administration behavior. Brain Res 457:287-294.

Terwilliger RZ, Beitner-Johnson D, Sevarino KA, Crain SM, Nestler EJ (1991) A general role for adaptations in G-proteins and the cyclic AMP system in mediating the chronic actions of morphine and cocaine on neuronal function. Brain Res 548:100-110.

Tjon GHK, De Vries TJ, Ronken E, Hogenboom F, Wardeh G, Mulder AH, Schoffelmeer ANM (1994) Repeated and chronic morphine administration cause differential long-lasting changes in dopaminergic neurotransmission in rat striatum without changes in $\partial$ - and $\kappa$-opioid receptor regulation. Eur J Pharmacol 252:205-212.

Undie AS, Friedman E (1994) Inhibition of dopamine agonist-induced phosphoinositide hydrolysis by concomitant stimulation of cyclic AMP formation. J Neurochem 63:222-230.

Unterwald EM, Fillmore J, Kreek MJ (1996) Chronic repeated cocaine administration increases dopamine $\mathrm{D}_{1}$ receptor-mediated signal transduction. Eur J Pharmacol 318:31-35.

Weed MR, Woolverton ML (1995) The reinforcing effects of $\mathrm{D}_{1}$ receptor agonists in rhesus monkeys. J Pharmacol Exp Ther 275:1367-1374.

Weed MR, Vanover KE, Woolverton WL (1993) Reinforcing effect of the $\mathrm{D}_{1}$ dopamine agonist SKF 81297 in rhesus monkeys. Psychopharmacology (Berl) 113:51-52.

Wise RA (1990) The role of reward pathways in the development of drug dependence. In: Psychotropic drugs of abuse (Balfour DJK, ed), pp 23-57. Oxford: Pergamon.

Woolverton WL (1986) Effects of a $D_{1}$ and a $D_{2}$ antagonist on the self-administration of cocaine and piribedil by rhesus monkeys. Pharmacol Biochem Behav 24:531-535.

Yamamoto KK, Gonzalez GA, Biggs WH, Montminy MR (1988) Phosphorylation-induced binding and transcriptional efficacy of nuclear factor CREB. Nature 334:494-498.

Yokel RA, Wise RA (1978) Amphetamine-type reinforcement by dopaminergic agonists in the rat. Psychopharmacology (Berl) 58:289-296. 